\title{
Seasonal variations and acclimation potential of the thermostability of photochemistry in four Mediterranean conifers
}

\author{
Fabienne FrouX ${ }^{\mathrm{a}, \mathrm{b}}$, Michel DUCREY $^{\mathrm{b}}$, Daniel EPRON $^{\mathrm{c}, \mathrm{d}}$, Erwin DREYER $^{\mathrm{a} *}$ \\ a UMR INRA-UHP, Écologie et Écophysiologie Forestières, 54280 Champenoux, France \\ b INRA, Unité de Recherches Forestières Méditerranéennes, avenue A. Vivaldi 84000 Avignon, France \\ ${ }^{c}$ Université de Franche-Comté, Institut des Sciences et des Techniques de l'Environnement, Laboratoire de Biologie et Écophysiologie, \\ BP 71427, 25211 Montbéliard Cedex, France \\ d Present address: UMR INRA-UHP, Écologie et Écophysiologie Forestières, BP 239, 54506 Vandœuvre, France
}

(Received 13 January 2003; accepted 20 August 2003)

\begin{abstract}
Thermostability of photosynthesis was studied in four Mediterranean conifer species growing in southern France, namely Cedrus atlantica and Pinus nigra growing usually on mid elevation areas, and Cupressus sempervirens and Pinus halepensis from coastal areas. Chlorophyll a fluorescence was used and lead to two indices assessing the degree of thermostability of the photosynthetic apparatus: the critical temperature at ground fluorescence breakpoint $\left(\mathrm{T}_{\mathrm{c}}\right)$ and the temperature threshold inducing a $15 \%$ decrease in photochemical efficiency $\left(\mathrm{T}_{15}\right)$. The two indices were correlated and yielded similar rankings among species, although mean values of $\mathrm{T}_{15}$ were $6.5^{\circ} \mathrm{C}$ lower than that of $\mathrm{T}_{\mathrm{c}}$ Values of $\mathrm{T}_{\mathrm{c}}$ were in the range 44 to $52{ }^{\circ} \mathrm{C}$ and clear interspecific differences were detected. $C$. atlantica consistently displayed higher $\mathrm{T}_{\mathrm{c}}$ than the other species $\left(1-1.5^{\circ} \mathrm{C}\right.$ difference during a seasonal time course). Among the three other species (C. sempervirens, P. nigra and P. halepensis), the differences were smaller and not always significant. $\mathrm{T}_{\mathrm{c}}$ also displayed a large intraspecific plasticity, with: $(i)$ a seasonal time-course showing significant increases during summer and lower values during Spring and Autumn; and (ii) large responses to ambient temperatures, with 5-6 ${ }^{\circ} \mathrm{C}$ increases in response to a gradual rise of temperature from 10 to $35^{\circ} \mathrm{C}$. The amplitude of the rise was of the same magnitude in all species. Therefore records of thermostability of photosynthesis, whatever the parameter used $\left(T_{c}\right.$ or $\left.T_{15}\right)$ need to take into account the large plasticity in this parameter when comparing species or genotypes. The degree of plasticity in response to given changes in micro-environment could be an important functional trait for the tolerance to environmental stresses.
\end{abstract}

high temperature / photosynthesis / Cedrus atlantica / Cupressus sempervirens / Pinus nigra / Pinus halepensis

Résumé - Variations saisonnières et potentiel d'acclimatation de la thermostabilité de la photochimie de quatre conifères méditerranéens. Nous avons analysé la thermostabilité de la photosynthèse de quatre conifères méditerranéens de la forêt française, le cèdre de l'Atlas (Cedrus atlantica) et le pin noir d'Autriche (Pinus nigra) qui occupent habituellement des zones de montagne, et le cyprès (Cupressus sempervirens) et le Pin d'Alep (Pinus halepensis) qui sont plus spécifiques des zones côtières. La fluorescence de la chlorophylle $a$ a permis d'estimer deux indices de thermostabilité de l'appareil photosynthétique : la température critique à la quelle la fluorescence de base augmente brutalement $\left(\mathrm{T}_{\mathrm{c}}\right)$, et le seuil de température induisant une baisse de $15 \%$ du rendement quantique de la photochimie $\left(\mathrm{T}_{15}\right)$. Ces deux indices étaient fortement corrélés et ont conduit au même classement des espèces, bien que les valeurs de $\mathrm{T}_{15}$ étaient en moyenne plus faibles de $6,5^{\circ} \mathrm{C}$ que celles de $\mathrm{T}_{\mathrm{c}}$. Les valeurs de $\mathrm{T}_{\mathrm{c}}$ couvraient la gamme de 44 à $52^{\circ} \mathrm{C}$ et des différences interspécifiques significatives ont été détectées. $C$ atlantica présentait des valeurs de $\mathrm{T}_{\mathrm{c}}$ systématiquement supérieures à celles des autres espèces, avec une différence de l'ordre de $1-1.5^{\circ} \mathrm{C}$ au cours d'une dynamique saisonnière. Parmi les 3 autres espèces (C. sempervirens, P. nigra et $P$. halepensis), les différences étaient plus faibles et pas toujours significatives. $\mathrm{T}_{\mathrm{c}}$ présentait aussi une très grande plasticité intra-spécifique, avec: $(i)$ une dynamique saisonnière très marquée présentant une augmentation significative au cours de l'été ainsi que des valeurs plus faibles pendant l'automne et le printemps; et (ii) une forte réponse à la température ambiante, avec une augmentation de l'ordre de $5-6^{\circ} \mathrm{C}$ en réponse à une graduelle augmentation de la température ambiante de 10 à $35^{\circ} \mathrm{C}$. L'amplitude de cette augmentations était similaire dans toutes les espèces. De ce fait, la caractérisation de la thermostabilité de la photosynthèse d'une espèce ou d'un génotype, quelque soit l'indice de thermostabilité utilisé $\left(\mathrm{T}_{\mathrm{c}}\right.$ or $\left.\mathrm{T}_{15}\right)$ doit prendre en compte la large plasticité de cette propriété. Le degré de plasticité de ce caractère, en réponse à des modifications du micro-climat, pourrait en soi constituer un trait fonctionnel important pour expliquer la tolérance des plantes à des contraintes environnementales, et particulièrement la chaleur.

température élevée / photosynthèse / Cedrus atlantica / Cupressus sempervirens / Pinus nigra / Pinus halepensis

\section{INTRODUCTION}

Sensitivity to high temperatures may partly control the spatial distribution of plant species [2]. High temperatures induce visi- ble damage on leaves [23], growth reductions in trees [22, 38] and affect photosynthesis primarily by severely impairing light driven electron transport and thylakoid stability [33]. Among the processes related to photochemistry, the most sensitive to

\footnotetext{
* Corresponding author: dreyer@ nancy.inra.fr
} 
increased temperature appear to be those related to PS II functions that are affected at lower temperatures than PS I and electron transfer between the two photosystems $[2,14]$.

The degree of thermostability may be estimated in vivo in leaves from the temperature threshold above which irreversible damage occurs in the photosynthetic apparatus. For this purpose, records of chlorophyll $a$ fluorescence under different temperatures may be a very useful tool [36]. As the fluorescence emission by PS II chlorophylls depends on the quantum yield of PS II photochemistry [5, 9], any temperature induced dysfunction of PS II should be reflected in the fluorescence signal. Several approaches have been designed to detect the temperature thresholds for dysfunctions. The most widely used is to record ground fluorescence $\left(\mathrm{F}_{\mathrm{o}}\right)$ on leaf samples submitted to a gradual increase of temperature at a rate of $1{ }^{\circ} \mathrm{C} \mathrm{min}^{-1}$ and to detect the rise of $\mathrm{F}_{\mathrm{O}}$, indicative of thermal damage to PS II, that defines a critical temperature for photochemistry $\left(T_{c}\right)[4$, 32]. Another method consists of measuring photochemical efficiency $\left(\mathrm{F}_{\mathrm{v}} / \mathrm{F}_{\mathrm{m}}\right)$ of dark adapted samples and notice the temperature at which it decreases significantly $[2,7]$.

This approach was used to screen genotypes for a potential variability in PS II thermostability. Such a variability was detected between two cultivars of Solanum tuberosum [15]. Knight and Ackerly [21] found significant but rather small differences among individuals from 35 different evergreen trees species originating from desert or sea shores, and grown under common conditions in a greenhouse. Similarly, two Mediterranean tree species, a conifer (Pinus halepensis) and an evergreen angiosperm (Quercus ilex) displayed very close values of therrmostability [28].

Comparisons of species and of genotypes are made difficult by the large capacity for acclimation that has been detected in many plants. For instance, acclimation to higher temperatures is accompanied by an upward shift of $\mathrm{T}_{\mathrm{c}}$ in several species [2]. High temperatures associated with large salt concentrations induced a significant increase of thermostability in Vigna unguiculata [24]. Similarly, light has been shown to protect to some extent PS II against high temperature induced damage [13]. A moderate drought stress increased significantly the thermostability in a range of species like Cedrus atlantica [7, 8,23 ] or Triticum sativum [27] and exogenous abscisic acid (ABA) increased PS II termostability in barley [19] and in cucumber [25]. Finally, increased $\mathrm{CO}_{2}$ resulted also in a larger thermostability of the photosynthetic apparatus [37].

Changes in thermostability can be very rapid. Short-term (very few hours) exposure to moderately high temperatures $\left(30-35^{\circ} \mathrm{C}\right)$ induced increases in potato [15] and in Picea abies [3]. One day at stepwise augmented temperatures resulted in large adjustments in Abies alba [31] and in Quercus suber seedlings [11]. Moreover, daily time courses of thermostability paralleled those of air temperature [39]. As a consequence of this large acclimation ability, any comparison of species needs be conducted under well-defined temperature and microenvironment. Moreover, single point comparisons may not really document potential differences among species, and the use of a large set of microenvironments may be requested to clearly establish the occurrence of interspecific differences.

The present work aimed at evidencing potential differences in thermostability and its acclimation potential in four Medi- terranean conifer species originating from contrasted areas with different altitudes and different thermal regimes. Species were Pinus nigra Arn., largely used in afforestation of mountain areas in the southern Alps, Cedrus atlantica Manetti, originating from Northern African mountains and introduced to the southern Alps at the end of the XIXth century; Cupressus sempervirens L. growing in the lowland close to the Mediterranean coast and Pinus halepensis Mill., pioneering species spreading naturally in the Mediterranean macchia.

We studied thermostability of photosynthesis with potted seedlings submitted to different microclimates, using the two approaches described above. We also assessed the plasticity of thermostability by measuring seasonal changes of $T_{c}$ in the four species, and by submitting the potted trees to increasing temperatures in a climate chamber.

\section{MATERIALS AND METHODS}

\subsection{Plant material}

Seeds from the four species (Cedrus atlantica Manetti, Pinus nigra Arn. ssp. nigricans Host. var. austriaca, Pinus halepensis Mill. and Cupressus sempervirens L.) were harvested in natural populations in South-Eastern France. During 1998 they were grown in «WM » containers at the nursery « Les Milles » close to Aix-en-Provence, France. During February 1999, the seedlings were transplanted to 71 pots containing a mixture of sand/peat/soil $(1 / 2 / 3, \mathrm{v} / \mathrm{v} / \mathrm{v})$ and grown in a greenhouse at Avignon, Southern-France, under approx. $85 \%$ of incident irradiance. They were watered once or twice a week with a $1 \%$ solution of fertiliser (Fertiligène, NPK 9/9/9). The greenhouse was kept frost-free over winter, and temperatures ranged between 25 and $32{ }^{\circ} \mathrm{C}$ during summer. Seedlings were sampled for experiments during March and August.

A similar experiment was set up during 2000, and 12 potted seedlings from each species were grown in a nursery at Avignon from March 2000 on. Minimal, maximal and mean temperatures were recorded daily. All others conditions were the same than during 1999.

\subsection{Chlorophyll a fluorescence measurement and thermostability assessment}

Chlorophyll a fluorescence was measured with a modulated fluorimeter (PAM 2000, Heinz Walz GmbH, Effeltrich, Germany) on detached needles that had been dark-adapted for 8 hours prior to harvest. Ground fluorescence $\left(\mathrm{F}_{\mathrm{o}}\right)$ was obtained with a low intensity modulated light $\left(600 \mathrm{~Hz}, 650 \mathrm{~nm}, \mathrm{PFD}<1 \mu \mathrm{mol} \mathrm{m}^{-2} \mathrm{~s}^{-1}\right)$. Maximal fluorescence $\left(\mathrm{F}_{\mathrm{m}}\right)$ was induced by a saturating flash (halogen lamp, $0.8 \mathrm{~s}$, $\left.4500 \mu \mathrm{mol} \mathrm{m}{ }^{-2} \mathrm{~s}^{-1}\right)$. The ratio $\mathrm{F}_{\mathrm{v}} / \mathrm{F}_{\mathrm{m}}$ was calculated as $1-\mathrm{F}_{\mathrm{o}} / \mathrm{F}_{\mathrm{m}}$ and was used as an estimate of maximal quantum yield of photochemistry [9].

(i) Response curves of $\mathrm{F}_{\mathrm{v}} / \mathrm{F}_{\mathrm{m}}$ to temperature were established as described earlier [7, 8]. Detached needles were placed into a temperaturecontrolled aluminium body with a window giving access to the fiberoptics of the fluorimeter. $\mathrm{F}_{\mathrm{v}} / \mathrm{F}_{\mathrm{m}}$ was measured at $20{ }^{\circ} \mathrm{C}$. The temperature of the aluminium body was increased from 20 to $50^{\circ} \mathrm{C}$ in successive 5 min. steps $\left(25,30,32,35,37,40,42,45,47,50{ }^{\circ} \mathrm{C}\right) . \mathrm{F}_{\mathrm{v}} / \mathrm{F}_{\mathrm{m}}$ was recorded at the end of each step. The temperature inducing a $15 \%$ decrease of $\mathrm{F}_{\mathrm{v}} / \mathrm{F}_{\mathrm{m}}$ with respect to the value at $20{ }^{\circ} \mathrm{C}$ was recorded (Fig. 1).

(ii) Response curves of $\mathrm{F}_{\mathrm{o}}$ to a temperature increase were recorded. Detached needles were placed into the same temperature-controlled aluminium body. Temperature was then increased gradually $\left(1^{\circ} \mathrm{C} \mathrm{min}-1\right)$ 

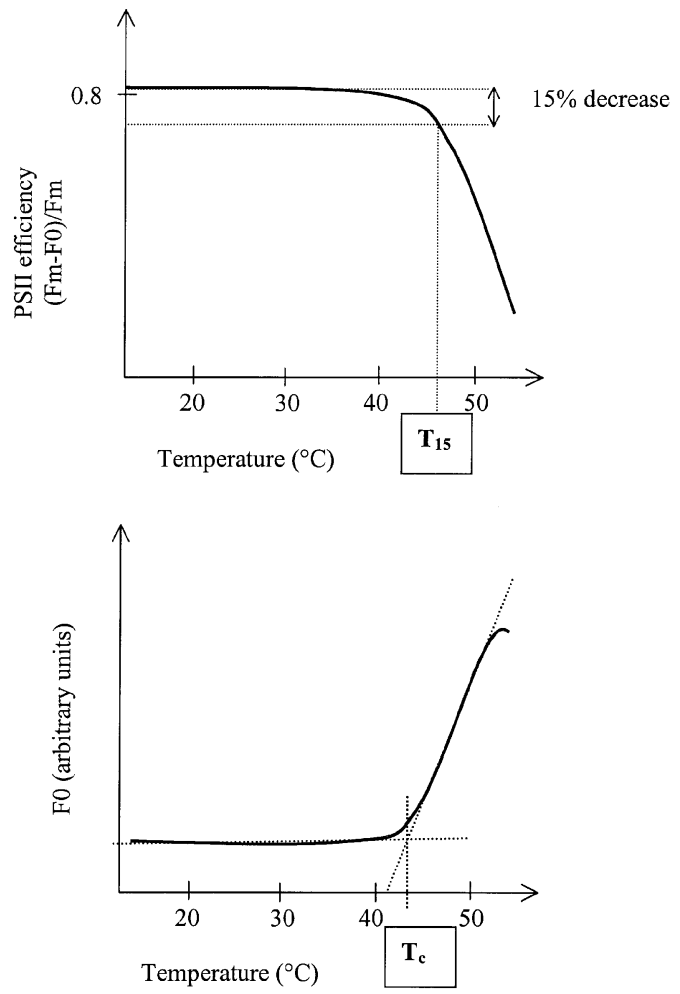

Figure 1. Traces of fluorescence vs. temperature used to estimate PS II thermostability. (a) from the temperature threshold when quantum yield of photochemistry $\left(\mathrm{F}_{\mathrm{v}} / \mathrm{F}_{\mathrm{m}}\right)$ decreases by $15 \%$ with respect to the value at $20^{\circ} \mathrm{C}$; leaf temperature was increased in 5 min steps $(25$, $\left.30,32,35,37,40,42,45,47,50{ }^{\circ} \mathrm{C}\right)$. (b) from the critical temperature $\mathrm{T}_{\mathrm{c}}$ above which ground fluorescence begins rising (inflexion point of the base line; temperature is increased gradually from 20 to $60{ }^{\circ} \mathrm{C}$ at a rate of $1{ }^{\circ} \mathrm{C} \mathrm{min}^{-1}$ ).

from 20 to $60{ }^{\circ} \mathrm{C}$. Critical temperature for stability of photochemistry $\left(\mathrm{T}_{\mathrm{c}}\right)$ was recorded from the inflexion point at the beginning of the steep increase of $F_{0}$ (Fig. 1), [4].

\subsection{Seasonal time course of thermostability of photochemistry}

During 2000, $\mathrm{T}_{\mathrm{c}}$ was recorded four times (beginning of April, beginning of May, end of August and end of October, i.e., days of year $109,138,241$, and 297) on needles of potted seedlings of C. sempervirens, $C$. atlantica, $P$. halepensis et $P$. nigra, grown in the nursery at Avignon. Six plants per species were placed into a climate chamber $\left(25^{\circ} \mathrm{C}, 12 \mathrm{~h}\right.$ light, PFD $\left.500 \mu \mathrm{mol} \mathrm{m} \mathrm{m}^{-2} \mathrm{~s}^{-1}\right)$ the day before the measurements, in order to standardize the temperature regime during the hours preceding measurements. The course of $F_{o}$ with increasing temperature was recorded as described above, after 12-15 hours acclimation to the standard temperature.

\subsection{Acclimation of thermostability to increasing temperatures}

During March and August 1999, 12 plants per species were transferred to a climate chamber (day/night: $14 / 10 \mathrm{~h} \mathrm{CO}_{2} 360 / 400 \mu \mathrm{mol}^{-1} \mathrm{~mol}^{-1}$, relative humidity: 60/80\%, PFD: $500 \mu \mathrm{mol} \mathrm{m}^{-2} \mathrm{~s}^{-1} / 0$ ). In March, the tem-

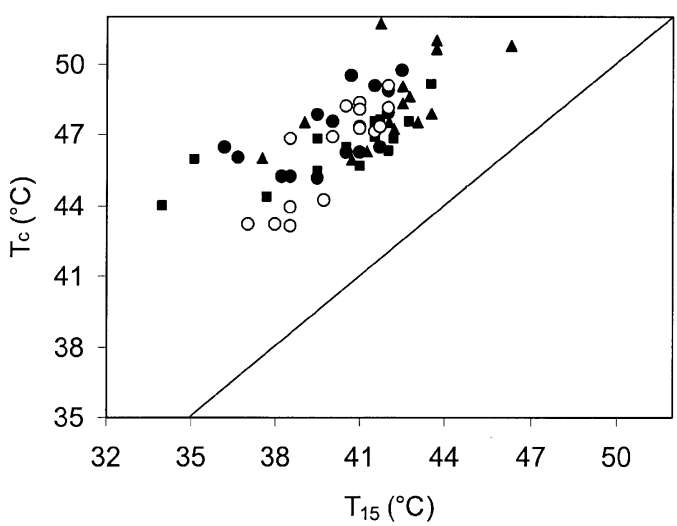

Figure 2. Relationship between $\mathrm{T}_{15}$ and $\mathrm{T}_{\mathrm{c}}$ recorded on needles of four different conifers. The linear correlation was statistically significant $(n=20, r=0,72, p<0.05)$. Current year needles of $P$. nigra (open disks), $P$. halepensis (squares), C. sempervirens (plain disks) and $C$. atlantica (triangles). The 1:1 line was drawn for clarity.

perature was preset at $10^{\circ} \mathrm{C}$ during a week and increased stepwise thereafter $\left(20,25\right.$ and $30^{\circ} \mathrm{C}, 5$ days per step). During August, the initial temperature was set to $20^{\circ} \mathrm{C}$ and the $5 \mathrm{~d}$. steps set at $25,30,35^{\circ} \mathrm{C}$. Needles were collected during the fourth day of each step. Half the needles were immediately used for estimating $T_{c}$ while the other half was. incubated during one hour in a thermostated bath at $35^{\circ} \mathrm{C}$ under darkness $[12,34] . \mathrm{T}_{\mathrm{c}}$ was measured after this incubation and compared to values of non-pretreated needles.

\section{RESULTS}

\subsection{Comparison of the two methods}

There was a significant, positive and linear correlation between the two variables $T_{15}$ and $T_{c}$, indicating a close coupling of the results from the two methods (Fig. 2, $n=20, r=$ $0,72, p<0.05)$. Moreover, the two methods yielded the same ranking in thermostability among the species $(C$. atlantica $>$ C. sempervirens $>P$. halepensis and $P$. nigra). Not surprisingly, the two methods yielded different values for $\mathrm{T}_{\mathrm{c}}$ and $\mathrm{T}_{15}$ (Fig. 2 and Tab. 1): species means ranged from 41.2 to $44.3{ }^{\circ} \mathrm{C}$ for $\mathrm{T}_{15}$ and from 47.2 to $51.0{ }^{\circ} \mathrm{C}$ for $\mathrm{T}_{\mathrm{C}}$. The mean difference between the two was about $6.5^{\circ} \mathrm{C}$. No species-specific deviation from the general correlation was detected, with the exception of $P$. nigra that displayed lower $T_{c}$ at low $T_{15}$ than the other species. The decrease of $F_{v} / F_{m}$ at $T_{15}$ was mainly due to the decline in maximal fluorescence $\left(\mathrm{F}_{\mathrm{m}}\right)$ with no visible change in ground fluorescence $\left(\mathrm{F}_{\mathrm{o}}\right.$, data not shown).

\subsection{Seasonal variability of critical temperature}

Mean ambient temperature recorded during 7 days before the sampling dates ranged from $14.3^{\circ} \mathrm{C}$ during Spring to $23.7^{\circ} \mathrm{C}$ during August (Fig. 3a). The amplitude of changes in mean temperature was 7.3 for minimal and $10.3{ }^{\circ} \mathrm{C}$ for the maximal temperatures from early April to end of October.

$\mathrm{T}_{\mathrm{c}}$ recorded on the saplings after $12 \mathrm{~h}$ acclimation at $25^{\circ} \mathrm{C}$, ranged from 43.7 to $50.8^{\circ} \mathrm{C}$ (Fig. 3b). An ANOVA followed by Fisher PLSD was used to assess the impact of seasonal variability 

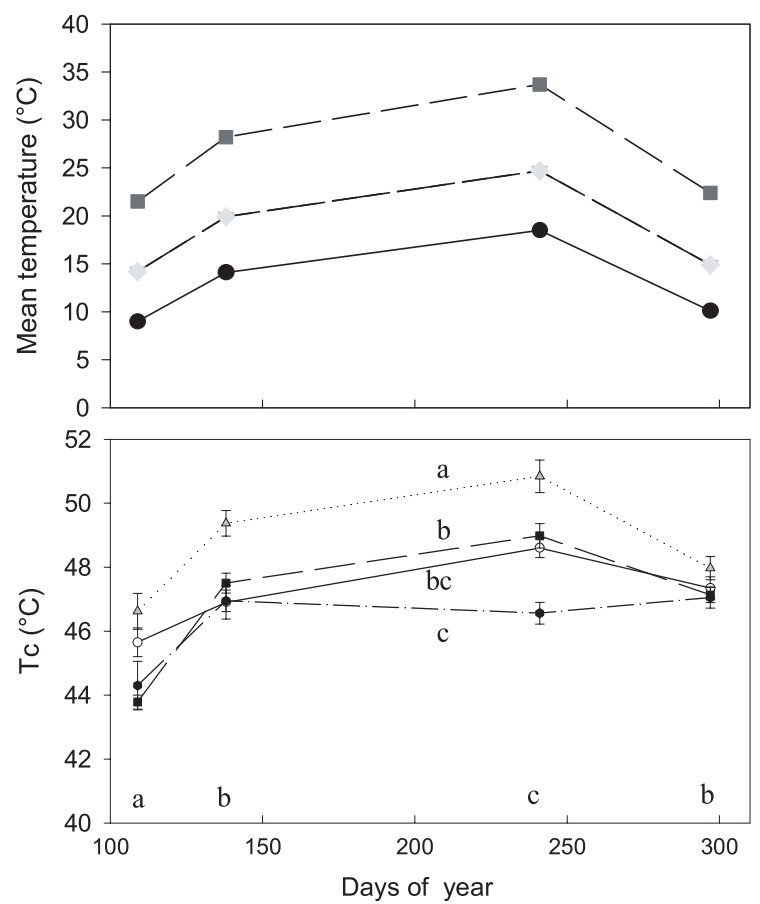

Figure 3. Seasonal time course of: (a) maximal (squares), mean (triangles) and minimal (disks) temperatures recorded during the seven days before measurements, (b) the critical temperature for PS II stability ( $\mathrm{T}_{\mathrm{c}}$ ), Current year needles of $P$. nigra (open disks), $P$. halepensis (squares), C. sempervirens (plain disks) and C. atlantica (triangles). In (b), means $\pm \mathrm{SEM} ; n=6$.

Table I. Comparison between two different indicators of PS II thermostability: the temperature threshold above which the quantum yield of photochemistry decreases by more than $15 \%$, and the critical temperature $\left(T_{c}\right)$ above which ground fluorescence $F_{o}$ increases. Data obtained during August 1999 with needles collected on saplings from four Mediterranean conifers, kept in a climate chamber at $30^{\circ} \mathrm{C}$ during 5 days. Means \pm SEM, $n=5$. Different letters within a column indicate significant differences (Duncan test, $p=0.05$ ).

\begin{tabular}{lccc}
\hline Species & $\mathrm{T}_{15}\left({ }^{\circ} \mathrm{C}\right)$ & $\mathrm{T}_{\mathrm{c}}\left({ }^{\circ} \mathrm{C}\right)$ & $\mathrm{T}_{\mathrm{c}}-\mathrm{T}_{15}\left({ }^{\circ} \mathrm{C}\right)$ \\
\hline C. atlantica & $44.3(1.7)^{\mathrm{a}}$ & $51.0(0.4)^{\mathrm{a}}$ & 6.7 \\
C. sempervirens & $41.5(1.0)^{\mathrm{b}}$ & $49.3(0.4)^{\mathrm{b}}$ & 7.8 \\
P. halepensis & $42.6(0.8)^{\mathrm{b}}$ & $47.9(0.7)^{\mathrm{c}}$ & 5.3 \\
P. nigra & $41.2(1.2)^{\mathrm{b}}$ & $47.2(1.8)^{\mathrm{c}}$ & 6 \\
\hline
\end{tabular}

and interspecific differences. A clear seasonal trend was identified $(p<0.0001)$ with an increase from April to August and a decrease from August to October. Interspecific differences were visible $(p<0.0001)$ and $C$. atlantica always displayed higher values than the three other species (by slightly more than $\left.1{ }^{\circ} \mathrm{C}\right)$. The three other species were much less clearly distinguished; nevertheless $P$. nigra displayed slightly higher values and $C$. sempervirens lower ones. The interaction between date and species effects was significant $(p=0.0025)$ although the ranking between $C$. atlantica and the other species was never modified. The time courses of $\mathrm{T}_{\mathrm{c}}$ of the four species were paral-
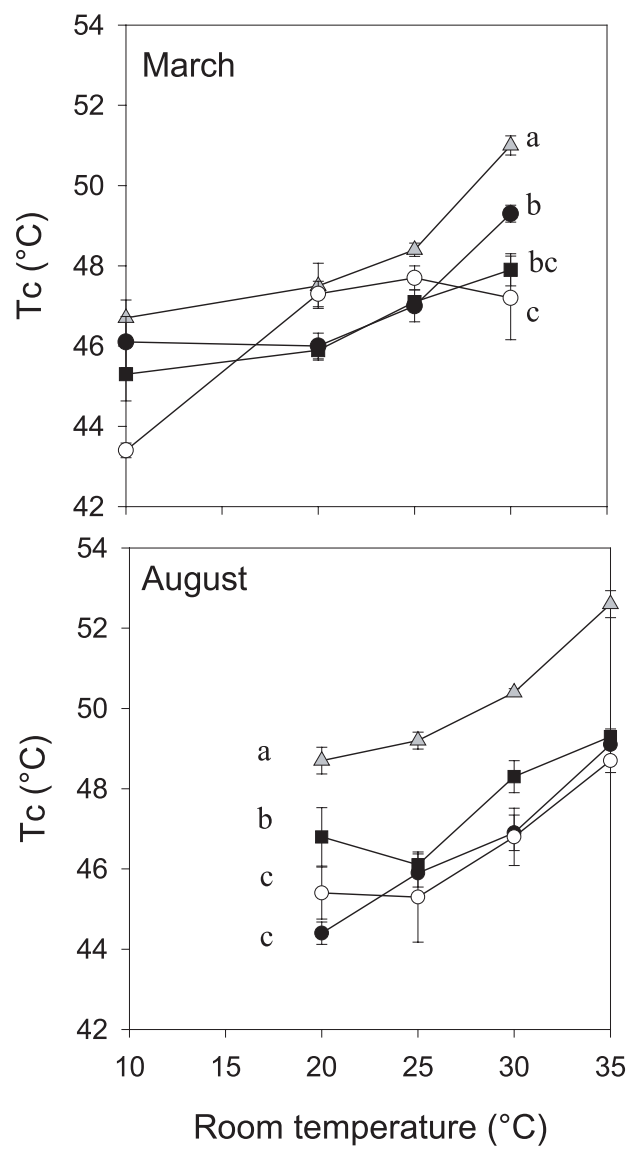

Figure 4. Relationship between the temperature in the climate chamber (maintained during 4 days prior to measurements) and the critical temperature $\mathrm{T}_{\mathrm{c}}$ of needles from $C$. atlantica, C. sempervirens, $P$. halepensis, and Pinus nigra measured either during March (open symbols) or August (closed symbols). Mean \pm SEM, $n=5$. Significant differences among critical temperatures are given by different letters ( $p=0.05$, Duncan test).

lel with that of mean temperatures (Fig. 3a) and a close correlation was found with ambient temperature (not shown), with nevertheless a hysteresis leading to higher $\mathrm{T}_{\mathrm{c}}$ during Autumn despite similar temperatures than during Spring $\left(1\right.$ to $3{ }^{\circ} \mathrm{C}$ higher values).

\subsection{Thermal acclimation}

The short-term plasticity of $\mathrm{T}_{\mathrm{c}}$ was tested on one-year-old needles during March and on current year needles during August in climate chambers using stepwise increases of temperature ( 5 days steps) imposed to whole seedlings. During the two experiments, $\mathrm{T}_{\mathrm{c}}$ increased in all species $(p<0.0001)$ in response to the stepwise increase of temperature. During March, $\mathrm{T}_{\mathrm{c}}$ increased by $4.3,3.1,3.2$, and $2.7^{\circ} \mathrm{C}$ in C. atlantica, C. sempervirens, $P$. nigra and $P$. halepensis, respectively, when room temperature was increased stepwise from 10 to $35^{\circ} \mathrm{C}$ (Fig. 4). During August, $\mathrm{T}_{\mathrm{c}}$ increased by $3.9,3.2,3.4$ and $2.5^{\circ} \mathrm{C}$ in the same species from 20 to $35^{\circ} \mathrm{C}$ ambient temperature (Fig. 4). All temperature steps resulted in significantly increased $\mathrm{T}_{\mathrm{c}}$ with respect to the preceding one, with the exception of the $20-25^{\circ} \mathrm{C}$ 
Table II. Increases of critical temperature for PS II thermostability $\left(\mathrm{T}_{\mathrm{c}}\right)$ after $1 \mathrm{~h}$ incubation at $35^{\circ} \mathrm{C}$. Needles of $C$ sempervirens, means \pm SEM, $n=5$. Significant increases are indicated by S, Duncan test, $p=0.05$.

\begin{tabular}{lcccc}
\hline $\begin{array}{l}\text { Ambient } \\
\text { temperature }\end{array}$ & \multicolumn{2}{c}{$\mathrm{T}_{\mathrm{c}}$} & $\Delta \mathrm{T}\left({ }^{\circ} \mathrm{C}\right)$ & $\begin{array}{c}\text { Effects of } \\
\text { incubation }\end{array}$ \\
\cline { 2 - 3 } & initial & after incubation & & \\
\hline $10{ }^{\circ} \mathrm{C}$ & $46.1 \pm 1.3$ & $48.4 \pm 0.2$ & 2.3 & $\mathrm{~S}$ \\
$20^{\circ} \mathrm{C}$ & $46.0 \pm 0.6$ & $48.1 \pm 0.4$ & 2.1 & $\mathrm{~S}$ \\
$25{ }^{\circ} \mathrm{C}$ & $47.0 \pm 0.5$ & $48.5 \pm 0.8$ & 1.2 & $\mathrm{~S}$ \\
$30^{\circ} \mathrm{C}$ & $49.3 \pm 0.4$ & $49.5 \pm 1.0$ & 0.2 & $\mathrm{NS}$ \\
\hline
\end{tabular}

transition during August. Values recorded during August and March were very close in $C$. atlantica and $P$. halepensis, but were lower by approx. $1.5^{\circ} \mathrm{C}$ during August in $C$. sempervirens and $P$. nigra. Significant interspecific differences appeared, and $C$. atlantica displayed systematically higher values of $\mathrm{T}_{\mathrm{c}}$ than the three other ones, at all levels of ambient temperature. During March, C. sempervirens differed from $P$. nigra, and during August $P$. halepensis was slightly above the two other species. Nevertheless, these differences remained rather low in comparison to the difference with $C$. atlantica.

\subsection{Very short term, temperature-induced increases in thermostability}

In order to study the very short term, temperature-induced increase in thermostability, the needles were further incubated at $35{ }^{\circ} \mathrm{C}$ for one hour after having been preconditioned stepwise from 10 to $30{ }^{\circ} \mathrm{C}$. A one hour incubation at $35^{\circ} \mathrm{C}$ had no detectable effect on $\mathrm{T}_{\mathrm{c}}$ in any species but in $C$. sempervirens. In this latter species the increase in $\mathrm{T}_{\mathrm{c}}$ ranged from $2.3{ }^{\circ} \mathrm{C}$ when the plant were first acclimated during 5 days at $10^{\circ} \mathrm{C}$ to $0.2^{\circ} \mathrm{C}$ when it was at $30{ }^{\circ} \mathrm{C}$ (Tab. II).

\section{DISCUSSION}

The two methods used to assess the thermostability of the photosynthetic apparatus, namely the temperature inducing a $15 \%$ decrease of quantum yield of PS II $\left(\mathrm{F}_{\mathrm{v}} / \mathrm{F}_{\mathrm{m}}\right)$ labelled $\mathrm{T}_{15}$ [8] and the critical temperature promoting a steep increase of ground fluorescence $\left(\mathrm{F}_{\mathrm{o}}\right)$, labelled $\mathrm{T}_{\mathrm{c}}$, [32] yielded closely correlated results with nevertheless different absolute values $\left(\mathrm{T}_{\mathrm{c}}\right.$ was on average $6.5^{\circ} \mathrm{C}$ above $\mathrm{T}_{15}$ ). As a matter of fact, the decrease observed in $\mathrm{F}_{\mathrm{v}} / \mathrm{F}_{\mathrm{m}}$ was due to a decrease in $\mathrm{F}_{\mathrm{m}}$ with no increase of $F_{0}$, which may be interpreted as indicating a reversible increase of thermal dissipation in PS II [2, 7]. The increase of $F_{O}$ is thought to express an irreversible decrease of the rate constant of photochemistry due to reaction centre disorganisation induced by excessive membrane fluidity [2]. Other parameters derived from $\mathrm{F}_{\mathrm{o}}$-temperature curves may be selected and are usually tightly correlated together [21]. We used $\mathrm{T}_{\mathrm{c}}$ as an index for the upper limit of stability of PSII because it is easily recorded with a standardised procedure and may be used for assessing the degree of plasticity in thermostability of photo-
Table III. Critical temperature for PS II thermostability estimated from the temperature inducing a ground fluorescence rise $\left(\mathrm{T}_{\mathrm{c}}\right)$. Ambient temperature at sample collection was always 20 or $25^{\circ} \mathrm{C}$.

\begin{tabular}{|c|c|c|c|}
\hline Species & & $\mathrm{T}_{\mathrm{c}}\left({ }^{\circ} \mathrm{C}\right)$ & Sources \\
\hline \multirow[t]{14}{*}{ Annuals } & Atriplex sabulosa & 41 & {$[32]$} \\
\hline & Desert species & $44.6-48.2$ & {$[21]$} \\
\hline & Coastal species & $44.1-48.9$ & {$[21]$} \\
\hline & Solanum tuberosum & 38.9 & {$[16]$} \\
\hline & Hordeum vulgare & 41.6 & {$[16]$} \\
\hline & Nicotiana tabacum. & 41.6 & {$[16]$} \\
\hline & Lycopersicon esculentum & 43.2 & {$[16]$} \\
\hline & Pisum sativum. & 42.3 & {$[16]$} \\
\hline & Pisum sativum & 42.5 & {$[10]$} \\
\hline & Phaseolus vulgaris & 41.7 & {$[16]$} \\
\hline & Phaseolus vulgaris. & 42 & {$[30]$} \\
\hline & Cucumis sativus low $\mathrm{CO}_{2}$ & 44.3 & {$[37]$} \\
\hline & Cucumis sativus high $\mathrm{CO}_{2}$ & 46.6 & \\
\hline & Zea mays & 47.6 & {$[16]$} \\
\hline \multirow[t]{8}{*}{ Broadleaved trees } & Populus tremuloides & 49.1 & {$[26]$} \\
\hline & Salix discolor & 47.4 & {$[26]$} \\
\hline & Quercus. robur & 47.6 & {$[6]$} \\
\hline & $Q$ petraea & 46.7 & {$[6]$} \\
\hline & Acer. pseudoplatanus & 47.5 & {$[6]$} \\
\hline & Betula verrucosa & 47.3 & {$[6]$} \\
\hline & Fagus excelsior & 47.0 & {$[6]$} \\
\hline & Fagus sylvatica & 46.3 & {$[6]$} \\
\hline \multirow[t]{8}{*}{$\begin{array}{l}\text { Mediterranean } \\
\text { trees and shrubs }\end{array}$} & Heteromeles arbutifolia & 48.5 & [39] \\
\hline & Pinus halepensis & 48.2 & {$[28]$} \\
\hline & Quercus ilex & 48.9 & {$[28]$} \\
\hline & Quercus suber & 44.1 & [11] \\
\hline & Pinus halepensis & 46.8 & This paper \\
\hline & Pinus nigra & 45.4 & This paper \\
\hline & Cupressus sempervirens & 44.4 & This paper \\
\hline & Cedrus atlantica & 48.7 & This paper \\
\hline
\end{tabular}

synthesis, although other indices, differing in their absolute values may be used in a similar way.

The four Mediterranean conifers (Pinus nigra, Pinus halepensis, Cedrus atlantica and Cupressus sempervirens) displayed a large plasticity in thermostability of PS II and in addition some interspecific differences in this property.

Interspecific differences of thermostability and $\mathrm{T}_{\mathrm{c}}$ are difficult to assess from the literature, because of the large differences in growth conditions that are know to induce acclimation shifts in $\mathrm{T}_{\mathrm{c}}$. Published values for plants grown under temperatures with maxima below $30{ }^{\circ} \mathrm{C}$ and acclimated briefly to temperatures around $25^{\circ} \mathrm{C}$ before measurements, range from 39 to $49{ }^{\circ} \mathrm{C}$ in annuals, from 46 to $49{ }^{\circ} \mathrm{C}$ in broadleaved tree species, and from 44 to 49 in Mediterranean trees and shrubs (Tab. III). It is difficult to draw any firm conclusion from such a data set due to uncertainties in the acclimation procedures used by different authors. Nevertheless, it is worth noting that Mediterranean 
conifer species displayed rather high values that nevertheless remained close to those recorded on mesophytic broadleaved species (Tab. III). A larger scale study was conducted under common garden conditions on con-generic desert and coastal species in a common garden experiment [21]. These authors found significant interspecific differences with values ranging from 43 to $52{ }^{\circ} \mathrm{C}$, species originating from desert displaying often (but not always) higher $\mathrm{T}_{\mathrm{c}}$ than coastal ones. Contrary to our expectations, we found no differences of $\mathrm{T}_{\mathrm{c}}$ between mountain (P. nigra and C. atlantica) and coastal species ( $P$. halepensis and $C$. sempervirens). C. atlantica, a mountain species in many North African and Southern France locations, displayed consistently the highest values of $\mathrm{T}_{\mathrm{c}}$. This species is known be submitted in its original habitat to very high temperatures during summer months [1].

Thermostability of PSII displayed a large plasticity in response to several environmental factors. Higher temperature during growth $[2,15]$, water stress $[7,13]$ or even application of exogenous ABA [19] are able to significantly increase $T_{c}$. Such increases may occur at a rather fast pace. $T_{c}$ was increased by $2 \mathrm{~h}$ at $35^{\circ} \mathrm{C}$ in potato [15]; our species responded less readily as only C. sempervirens reacted with increasing $\mathrm{T}_{\mathrm{c}}$ after $1 \mathrm{~h}$ at $35^{\circ} \mathrm{C}$. Although the ability of $\mathrm{T}_{\mathrm{c}}$ and thermostability of photosynthesis to acclimate and therefore to display an important phenotypic plasticity is now well recognised, experimental data quantifying the amplitude of long term responses are still seldom. Growth under high $\mathrm{CO}_{2}$ concentrations (750 vs. $350 \mu \mathrm{mol} \mathrm{mol}^{-1}$ ) led to an increase of $\mathrm{T}_{\mathrm{c}}$ by $2.4^{\circ} \mathrm{C}$ [37]. Similarly, drought resulted in a $8{ }^{\circ} \mathrm{C}$ increase of $\mathrm{T}_{\mathrm{c}}$ in Quercus suber [11]. Drought stress was recognised to have the potential to induce a long lasting shift towards higher thermotolerance [7, 23]. Besides these data, only few descriptions of the dynamic response of $\mathrm{T}_{\mathrm{c}}$ to temperature were available. Here we demonstrated the large ability of different conifer species to acclimate to higher temperature by shifting $\mathrm{T}_{\mathrm{c}}$ by 5 to $8{ }^{\circ} \mathrm{C}$ depending on species when ambient temperatures shifted from 10 to $35^{\circ} \mathrm{C}$. To our knowledge, there are no comparable studies that would help compare this range with those obtained on other species, with the exception of Quercus suber, in which $\mathrm{T}_{\mathrm{c}}$ increased by almost $10^{\circ} \mathrm{C}$ when ambient temperatures were shifted from 10 to $40{ }^{\circ} \mathrm{C}[11]$.

Similarly, seasonal time courses of thermotolerance resulted in a large plasticity of $\mathrm{T}_{\mathrm{c}}$ in the four species, with changes by as much as $4{ }^{\circ} \mathrm{C}$ despite a standardisation of the temperatures (at $20^{\circ} \mathrm{C}$ ) during $24 \mathrm{~h}$ before the measurements. Summer temperatures resulted in larger values of $\mathrm{T}_{\mathrm{c}}$ than during spring or autumn. The seasonal time course was tightly related to that of ambient temperature, confirming earlier findings [2, 33]. This seasonal effect may be combined with a needle age effect; in maize, younger leaves displayed a larger thermostability than older ones [20]. Interestingly, values recorded after summer were higher than during spring despite similar thermal regimes before needle collection. This latter observation reveals a hysteresis in the relationships between ambient temperature and $\mathrm{T}_{\mathrm{c}}$, the increase in $\mathrm{T}_{\mathrm{c}}$ with increasing temperatures being faster than the relaxation from this effect. Similarly, drought preconditioned cedars are know to display higher thermotolerance than control ones and to maintain this acquired thermotolerance long after rehydration [23]. A still open question is therefore that of the reversibility of the acclimation to high temperature; to our knowledge there are no data to document the dynamics of decreases of $\mathrm{T}_{\mathrm{c}}$ following return to lower temperatures. Relaxation of this environmentally-induced thermotolerance would therefore deserve additional attention.

The physiological basis of adjustments and acclimations to temperature is still under debate. Thermostability of photosynthesis may be related to thylakoid membrane fluidity [2, 29], that might be partly controlled by the concentration of free zeaxanthin and therefore the inter-conversion process between violaxanthin and zeaxanthin [18]. Isoprene emitted by several species has been suggested to contribute to the thylakoid stability $[34,35]$ although this point is still debated [26]. Low molecular weight heat shock proteins might also play the role of chaperonine protecting protein complexes of the chloroplastic electron transport chain against heat denaturation [19]. The underlying mechanism of such a large acclimation response to many environmental stimuli remains still to be elucidated.

\section{CONCLUSION}

In this work, we evidenced that the critical temperature for ground fluorescence rise $\left(\mathrm{T}_{\mathrm{c}}\right)$, and the temperature inducing a $15 \%$ decline of the quantum yield of photochemistry $\left(\mathrm{T}_{15}\right)$ used as indicators of photosynthetic thermostability, were strongly correlated. They were consistently larger in Cedrus atlantica than in the three other species. $\mathrm{T}_{\mathrm{c}}$ also displayed a large plasticity, increasing during summer and in response to increasing ambient temperature. Taking into account the large variability of data published in the literature, it is almost impossible to clearly rank species or genotypes according to their $\mathrm{T}_{\mathrm{c}}$ values under common conditions. Additional experiments with large scale screening would be required. Moreover, if we now have some data describing the rise of $\mathrm{T}_{\mathrm{c}}$ with temperature, there still is a need to assess the degree of reversibility of $\mathrm{T}_{\mathrm{c}}$ with decreasing temperatures, or after any other acclimation process, as it may be assumed that the adaptation to hot climates may be related to the acclimation potential of thermostability rather than to the actual levels under a reference ambient microclimate.

Acknowledgements: F. Froux was supported by a grant from the French Ministery for Education and Research. Didier Bethored and Arnaud Jouinau produced and maintained the plant material at INRA Avignon, and Jean Marie Gioria at INRA Nancy. Patrick Gross (INRA Nancy) designed the device used to measure the critical temperature.

\section{REFERENCES}

[1] Aussenac G., Le cèdre, essai d'interprétation bioclimatique et écophysiologique, Bull. Soc. Bot. Fr. 131 (1984) 385-398.

[2] Berry J., Björkman O., Photosynthetic response and adaptation to temperature in higher plants, Ann. Rev. Plant Physiol. 31 (1980) 491-543.

[3] Bigras F.J., Selection of white spruce families in the context of climate change: heat tolerance, Tree Physiol. 20 (2000) 1227-1234.

[4] Bilger H.W., Schreiber U., Lange O.L., Determination of leaf heat resistance: comparative investigation of chlorophyll fluorescence changes and tissue necrosis methods, Oecologia 63 (1984) 256-262.

[5] Butler W.L., Energy distribution in the photochemical apparatus of photosynthesis, Ann. Rev. Plant Physiol. 29 (1978) 345-378. 
[6] Dreyer E., Le Roux X., Montpied P., Daudet F.A., Masson F., Temperature response of leaf photosynthetic capacity in seedlings from seven temperate tree species, Tree Physiol. 21 (2001) 223-232.

[7] Epron D., Effects of drought on photosynthesis and on the thermotolerance of photosystem II in seedlings of cedar (Cedrus atlantica and C. libani), J. Exp. Bot. 48 (1997) 1835-1841.

[8] Epron D., The temperature dependence of photoinhibition in leaves of Phaseolus vulgaris $\mathrm{L}$. Influence of $\mathrm{CO}_{2}$ and $\mathrm{O}_{2}$ concentrations, Plant Sci. 124 (1997) 1-8.

[9] Genty B., Briantais J.M., Baker N.R., The relationship between the quantum yield of photosynthetic electron transport and quenching of chlorophyll fluorescence, Biochim. Biophys. Acta. 990 (1989) $87-92$.

[10] Georgieva K., Yordanov I., Temperature dependence of chlorophyll fluorescence parameters of pea seedlings, J. Plant Physiol. 142 (1993) 151-155.

[11] Ghouil H., Montpied P., Epron D., Ksontini M., Hanchi B., Dreyer E., Thermal optima of photosynthetic functions and thermostability of photochemistry in cork oak seedlings, Tree Physiol. 23 (2003) 1031-1039.

[12] Havaux M., La fluorescence de la chlorophylle in vivo : quelques concepts appliqués à l'étude de la résistance de la photosynthèse aux contraintes de l'environnement, in: Tolérance à la sécheresse des céréales en zone méditerranéenne. Diversité génétique et amélioration variétale, Montpellier, France, Paris, 1992.

[13] Havaux M., Stress tolerance of photosystem II in vivo. Antagonistic effects of water, heat and photoinhibition stresses, Plant Physiol. 100 (1992) 424-432.

[14] Havaux M., Characterization of thermal damage to the photosynthetic electron transport system in potato leaves, Plant Sci. 94 (1993) 19-33.

[15] Havaux M., Rapid photosynthetic adaptation to heat stress triggered in potato leaves by moderately elevated temperatures, Plant Cell Environ. 16 (1993) 461-467.

[16] Havaux M., Strasser R.J., Greppin H., In vivo photoregulation of photochemical and non-photochemical deactivation of photosystem II in intact plant leaves, Plant Physiol. Biochem. 28 (1990) 735-746.

[17]Havaux M., Tardy F., Ravenel J., Chanu D., Parot P., Thylakoid membrane stability to heat stress studied by flash spectroscopic measurement of the electochromic shift in intact potato leaves: influence of the xanthophyll content, Plant Cell Environ. 19 (1996) 1359-1368.

[18] Heckathorn S.A., Downs C.A., Sharkey T.D., Coleman J.S., The small methionine rich chloroplast Heat Shock Protein protects photosystem II electron transport during heat stress, Plant Physiol. 116 (1998) 439-444.

[19] Ivanov A.G., Kitcheva M.I., Christov A.M., Popova L.P., Effects of abscissic acid treatment on the thermostability of the photosynthetic apparatus in barleys chloroplasts, Plant Physiol. 98 (1992) 1228 1232.

[20] Karim M.A., Fracheboud Y., Stamp P., Photosynthetic activity of developing leaves of Zea mays is less affected by heat stress than that of developed leaves, Physiol. Plant. 105 (1999) 685-693.

[21] Knight C.A., Ackerly D.D., An ecological and evolutionary analysis of photosynthetic thermotolerance using the temperature-dependent increase in fluorescence, Oecologia 130 (2002) 505-514.
[22] Kolb P.F., Robberecht R., High temperature and drought stress effects on survival of Pinus ponderosa seedlings, Tree Physiol. 16 (1996) 665-672.

[23] Ladjal M., Epron D., Ducrey M., Effects of drought preconditioning on thermotolerance of photosystem II and susceptibility of photosynthesis to heat stress in cedar seedlings, Tree Physiol. 20 (2000) $1235-1241$.

[24] Larcher W., Wagner J., Thammathaworn A., Effects of superimposed temperature stress on in vivo chlorophyll fluorescence of Vigna unguiculata under saline stress, J. Plant Physiol. 136 (1990) 92-102.

[25] Li Z., Oda M., Okada K., Sasaki H., Changes in thermotolerance of photosynthetic apparatus in cucumber leaves in response to water stress and exogenous ABA treatments, J. Japan Soc. Hortic. Sci. 65 (1996) 587-594.

[26] Logan B.A., Monson R.K., Thermotolerance of leaf discs from four isoprene-emitting species is not enhanced by exposure to exogenous isoprene, Plant Physiol. 120 (1999) 821-825.

[27] Lu C., Zhang J., Effects of water stress on photosystem II photochemistry and its thermostability in wheat plants, J. Exp. Bot. 50 (1999) $1199-1206$

[28] Méthy M., Gillon D., Houssard C., Temperature-induced changes of photosystem II activity in Quercus ilex and Pinus halepensis, Can. J. For. Res. 27 (1997) 31-38.

[29] Murata N., Los D.A., Membrane fluidity and temperature perception, Plant Physiol. 115 (1997) 875-879.

[30] Pastenes C., Horton P., Resistance of photosynthesis to high temperature in two bean varieties (Phaseolus vulgaris), Photosynth. Res. 62 (1999) 197-203.

[31] Robakowski, P., Montpied P., Dreyer E., Temperature response of photosynthesis in silver fir (Abies alba) seedlings, Ann. For. Sci. 59 (2002) 163-170.

[32] Schreiber U., Berry J.A., Heat-induced changes of chlorophyll fluorescence in intact leaves correlated with damage of the photosynthetic apparatus, Planta 136 (1977) 223-238.

[33] Seemann J.R., Downton W.J.S., Berry J.A., Temperature and leaf osmotic potential as factors in the acclimation of photosynthesis to high temperature in desert plants, Plant Physiol. 80 (1986) 926-930.

[34] Sharkey T.D., Singsaas E.L., Why plants emit isoprene, Nature 374 (1995) 769.

[35] Singsaas E.L., Laporte M.M., Shi J.-Z., Monson R.K., Bowling D.R., Johnson K., Lerdau M., Jasentuliytana A., Sharkey T.D., Kinetics of leaf temperature fluctuation affect isoprene emission from red oak (Quercus rubra) leaves, Tree Physiol. 19 (1999) 917-924.

[36] Smillie R.M., Hetherington S.E., Stress tolerance and stress-induced injury in crop plants measured by chlorophyll fluorescence in vivo: chilling, freezing, ice cover, heat, and high light, Plant Physiol. 72 (1983) 1043-1050.

[37] Taub D.R., Seemann J.R., Coleman J.S., Growth in elevated $\mathrm{CO}_{2}$ protects photosynthesis against high-temperature damage, Plant Cell Environ. 23 (2000) 649-656.

[38] Teskey R.O., Will R.E., Acclimation of loblolly pine (Pinus taeda) seedlings to high temperatures, Tree Physiol. 19 (1999) 519-525.

[39] Valladares F., Pearcy R., Interactions between water stress, sun-shade acclimation, heat tolerance and photoinhibition in the sclerophyll Heteromeles arbutifolia. Plant Cell Environ. 20 (1997) 25-36. 